\title{
Public Policy for Regulating the Interaction between Labor Market Supply and Higher Education Demand - Israel as a Case Study.
}

\author{
Erez Cohen \\ Department of Middle Eastern Studies - Political Science. Ariel University, Israel.
}

\begin{abstract}
The global labor market in general and the Israeli market in particular have been experiencing considerable changes in recent decades, affecting the supply of jobs in various occupations. There seems to be an association between changes in the supply of jobs in the labor market and shifts in the demand for higher education. Examination of two case studies in the Israeli economy shows a bidirectional interaction between the labor market and the system of higher education. In one case, the growing supply of jobs in the field of computers and engineering was found to result in an increasing demand for academic education in this discipline. In the second case, the growing demand for academic education in law resulted in a flooded labor market in this industry with bad effects for the industry. The public policy formed in Israel to regulate the labor market and the system of higher education is aimed at the short term and makes do with examining actual circumstances retrospectively and attempting to improve them by directing students to various disciplines in order to meet the needs of the labor market or correct its failures. It does not, however, examine future trends and try to identify prospective needs and faults that can be predicted in the present.
\end{abstract}

Key Words: Public policy, labor market, higher education, Israel Economy.

\section{Introduction}

The global labor market in general and the Israeli market in particular have been experiencing considerable changes in recent decades and expect to see additional changes in the coming decades. These changes originate from demographic, technological, gender-related, perceptual, and economic shifts that are influencing the labor market on various dimensions including, among others, the structure of the market, the role of new technologies in the market, relationships between employees and employers, and the market's workforce needs.

There seems to be an association between changes in the supply of jobs in the labor market and shifts in the demand for higher education, as the need for educated workers in highdemand fields raises the motivation of young people to acquire an education in these fields. 


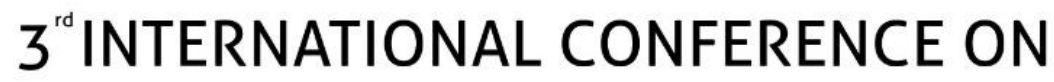 FUTURE OF TEACHING \& EDUCATION}

\section{Stockholm, Sweden}

\section{9-11 October 2020}

Then again, a major inclination of young people to acquire an education in a certain discipline might develop and expand the number of jobs in this occupation when they complete their academic training or, alternately, increase the supply of workers in that industry, leading to higher unemployment within it.

The research literature includes many different studies on the interaction between the labor market and the system of higher education from various perspectives. One conspicuous example is the study conducted by Albert, who examined the association between changes in the labor market in Spain and the local system of higher education (Albert, 2000).

Assaad, Krafft \& Salehi-Isfahani examined the assumption that the type of higher education affect labor market outcomes focusing on Egypt and Jordan (Assaad, Krafft, \& SalehiIsfahani, 2018). Etshim examined the collaboration between higher education and labor market in Congo (Etshim, 2017). Elias and Purcell examined the contribution of the system of higher education to the job market (2004). Then again, Brennan and his associates raised doubts as to the power of higher education to adequately prepare graduates for the job market and enable them to find suitable, proper, and gratifying jobs (Brennan, Murray, McGeevor, \& Lyon, 1993).

Further to these studies and in contrast to them, the current study focuses on an examination of public policy regulating the interaction between changes in the supply of jobs in various occupations within the Israeli labor market from the beginning of the current century and shifts in demand for higher education in these disciplines during this period. The study has four goals: First, to establish the interaction between trends concerning changes in the labor supply and trends concerning the demand for higher education. Second, to determine the direction of this interaction. Namely, do changes in the supply of jobs in the economy in a given period eventually affect trends regarding the demand for higher education programs, or is the opposite true: the demand for further specialization in a certain field in a given period, as evident at institutions of higher education, affects the future labor market and the supply of jobs within it. Third, to examine the public policy implemented in Israel from the beginning of the current decade, policy capable of affecting one or both of these trends. Finally, to offer decision makers recommendations with regard to necessary changes in the nature of policy concerning regulation of the system of higher education and its adaptation to the demands of the dynamic labor market.

Governments and organizations around the world have reached an understanding of the need for rational planning in preparation for the needs of the developing job market and, indeed, in recent years we have witnessed various studies that attempt to predict future trends in the job market. A study conducted in the US by Frey and Osborne sought to predict long-term changes in the American labor market. The study's conclusions determine that in up to two decades nearly half of all occupations in the US will be at high risk of disappearing, at least partially, following the development of computerization, robotics, and automation technologies that will replace human beings employed in them at present (Frey \& Osborne, 2017). These forecasts were enhanced by a publication of the US Bureau of Labor Statistics, which projects that by 2024 the US will see the disappearance of 339,300 jobs in the fields of manufacturing and agriculture. 


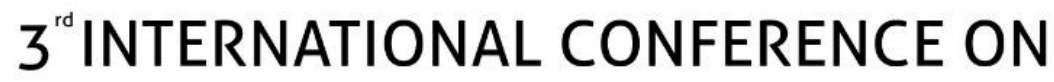 FUTURE OF TEACHING \& EDUCATION}

\section{Stockholm, Sweden}

\section{9-11 October 2020}

${ }^{1}$ Similarly, the World Economic Forum conducted a survey of employers with the purpose of predicting anticipated short-term trends in the future labor market and determined that by 2020 millions of jobs concentrated in several industries are predicted to disappear (World Economic Forum, 2016). ${ }^{2}$

In order to establish conclusions with regard to predicted changes in the job market, and mainly in order to adequately prepare for these changes, policy makers must learn and analyze both the overall influencing factors, such as technological, social, economic, and demographic shifts, ${ }^{3}$ and the expected impact of these shifts on various social domains, including the local system of higher education.

One of the major factors affecting changes in the labor market are the skills required by the market. As a result of the accelerated pace of technological change, the skills necessary to hold a job are changing rapidly, leading to increasing incompatibility between the demand for and supply of skills. In a study conducted in 2012, Dobbs et al. predicted a global shortage of millions of high-skilled workers, ${ }^{4}$ concurrent with a surplus of millions of low-skilled workers (Dobbs et al., 2012). ${ }^{5}$ General and demographic changes also influence the labor market and require renewed thinking with regard to employment arrangements and the integration of older workers in this market. The rise in life expectancy in developed countries in recent years is manifested in an increase in the relative proportion of older workers. The implications of these changes have been recognized and are receiving increasing scientific attention (Staudinger, Finkelstein, Calvo, \& Sivaramakrishnan, 2016; Van Dalen, Henkens, \& Schippers, 2010; Parry \& McCarty, 2017; Braw, Cohen, Brender-Ilan, \& Sohlberg, 2018).

In addition, social changes that increase workers' need for independence, initiative, and personal development have a not inconsiderable contribution to transitions in demand and supply forces within the labor market and require consideration of new employment forms and appropriate legislation (Hamilton, 2000). Other social changes that might affect the labor market involve the level of education in society and the distribution of its training structure. The more educated the society the greater workers' demand to obtain academic positions that grant prestige, honor, and high income levels and enable employees to express and realize their education and thinking and to climb the socioeconomic ranks. ${ }^{6}$ Accordingly, workers' demand to occupy jobs that require no extensive education and that do not let employees improve their socioeconomic status will diminish (Davidovitch, Byalsky, Soen, \& SinuaniStern, 2013). ${ }^{7}$

The promotion of public policy that examines, plans, and prepares for transitions in the economy's structure of employment is an important and even essential step in a period characterized by rapid technological development. Technological development in a given economy may result in the transformation of study and educational trends in that economy and thus lead to the disappearance of existing jobs and the formation of new jobs and occupations. Such a process occurred in the world in the late twentieth century, when development of the worldwide computer industry raised the demand for educated and skilled workers in this field (Frey \& Osborne, 2017).

Similar to the global trend at that time, in Israel as well the development pace of advanced industry gathered momentum from the early 1990s until the end of the twentieth century. This

\section{info@icfte.com_www.icfte.com}




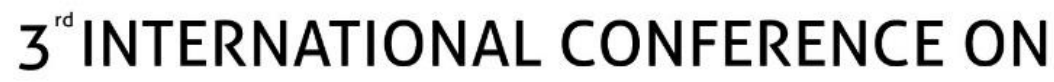 FUTURE OF TEACHING \& EDUCATION}

\section{Stockholm, Sweden}

\section{9-11 October 2020}

development was accompanied by an increase in all aspects of advanced industry in Israel, including the number of employees. Consequently, the structure of Israeli industry changed, with advanced industry occupying a growing part in the entire Israeli economy (Cohen, 2015). Concurrent with the change in the structure of Israeli employment and industry, a real revolution was also evident in the structure of Israeli higher education. In 1993 a reform was introduced in Israel's system of higher education ${ }^{8}$, leading in about one decade to a deep transformation in opportunities for acquiring an academic education in Israel. As a result of this reform, Israel's system of higher education changed completely and since the early 1990s the universities have been supplemented by many colleges, forming a more extensive and open structure of higher education that includes a wide range of disciplines. As a result, the system of higher education doubled in size in only one decade, with the high demand for academic studies and the opening of new institutions of higher education joining to create a different reality that constitutes a new point of balance between supply and demand (Cohen \& Davidovitch, 2015). The effects of these two trends on the Israeli labor market on one hand and on the local system of higher education on the other will be presented in the Findings chapter.

Hence, it seems that the government must prepare in advance and identify prospective changerelated trends predicted for various reasons in higher education and in the local job market, since adequate preparation can maintain the relevance of institutions of higher education and protect the local economy from phenomena of personnel surpluses and shortages in specific fields. Indeed, there are examples of government attempts to foresee and prepare for changes in the labor market and in higher education. A conspicuous example of such an attempt is evident in the study conducted by Frey, Osborne, Holmes, Rahbari, Garlick, Friedlander and Wilkie, ${ }^{9}$ who examined anticipated changes in several OECD countries and indicated several professions and occupations that might disappear in those countries as a result of technology and automation processes. The researchers contend that in order to prepare for prospective changes in the labor market, there is need for stronger collaboration between education, training, and employment to generate a better and more efficient fit between teaching and training trends and the future labor market (Frey et al., 2016).

\section{Method}

The process of the research method is as follows: presenting the research's hypotheses, then presenting facts and data, refuting or confirming the hypotheses according to the information, and finally - reaching conclusions. The association between the supply of jobs in the labor market and the demand for higher education in Israel as well as the direction of this association will be examined based on employment trends and registration for the various study programs in select periods. These trends will be gleaned from data available from the Israeli Central Bureau of Statistics and from the website of the Council for Higher Education. Presentation and analysis of public policy with regard to planning Israel's future labor market are based on reports by government research and information centers, such as the Knesset Research and Information Center and the annual budget books of the Council for Higher Education (produced by the Planning and Budgeting Committee, PBC). Policy analysis will also utilize research and publications by various research and political institutions, such as the Israel Democracy Institute. In addition, the research findings are based on position papers

\section{info@icfte.com}




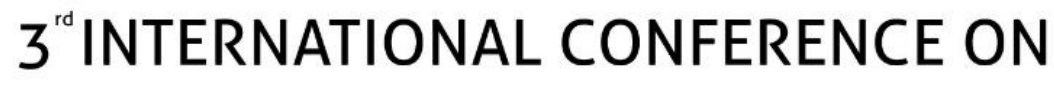 FUTURE OF TEACHING \& EDUCATION}

\section{Stockholm, Sweden}

\section{9-11 October 2020}

produced by various government organs, such as the Bank of Israel, the National Insurance Institute, the Government Employment Agency, the Ministry of Finance, the Ministry of Economy and Industry, and the Ministry of Labor.

\section{Results}

The first purpose of this study was, as stated, to examine and analyze the interactions between changes in the supply of jobs within the local labor market and trends concerning the demand for higher education. Then, the study sought to examine public policy implemented in order to regulate these interactions, with the Israeli economy serving as a case study.

\subsection{Examination of the association between the supply of jobs in the labor market and the demand for higher education as well as the direction of this association}

3.1.1 The supply of jobs in Israel's advanced industries versus the demand for technological and scientific studies

As shown in the Introduction, two processes characterized the Israeli economy in the early 1990s: one - rapid technological development that led to expansion of the advanced industries, and the other - a reform in the system of higher education that facilitated the opening of dozens of new academic institutions in Israel. The combination of these two trends enabled the development of an uncontrolled free market that affected trends of supply and demand in the local labor market and trends concerning registration for academic studies. Consequently, the change in the structure of the local labor market created a high demand for technological workers and a large supply of attractive jobs, and began to affect the demand for relevant higher education. Therefore, in those years academic programs in the exact sciences and technological sciences ${ }^{10}$ began to develop rapidly, as presented in the following figure.

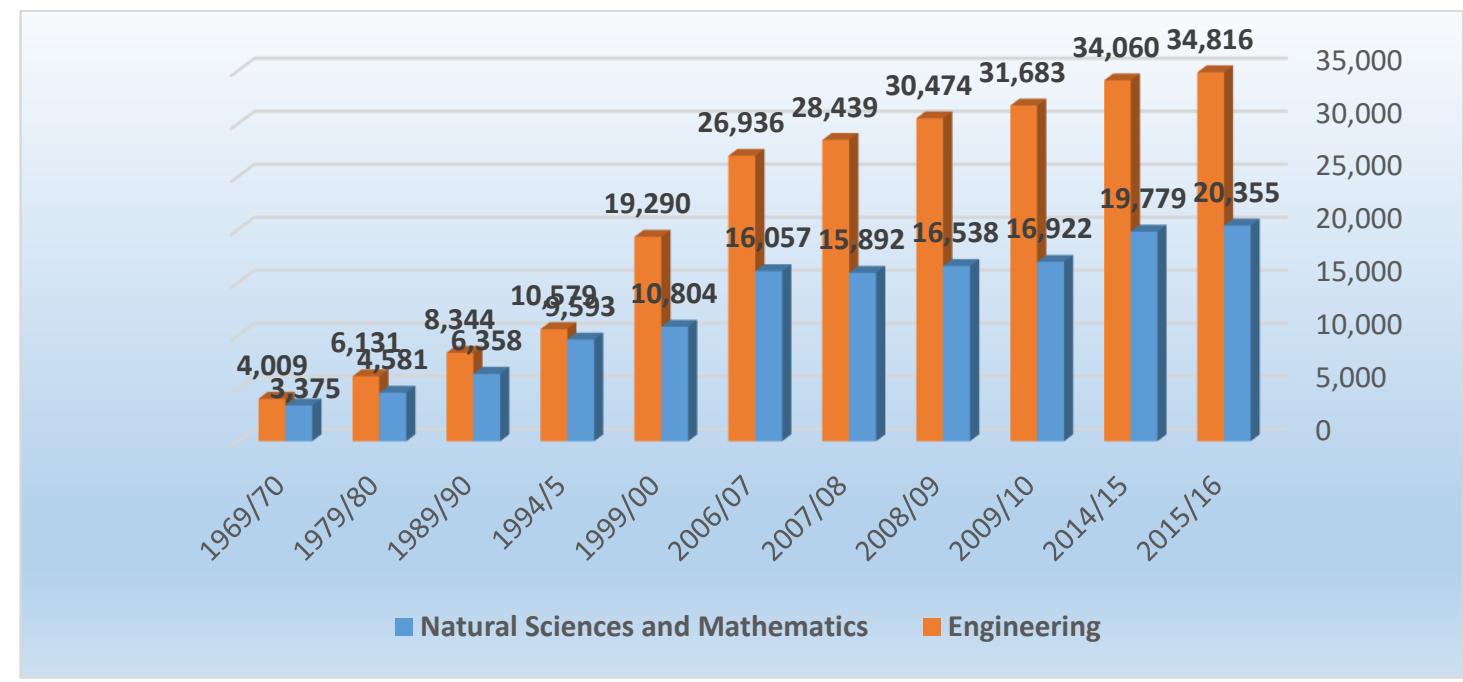

Figure 1 - Baccalaureate degree students in Israel: natural sciences and mathematics and engineering.

Source: Israeli CBS (Central Bureau of Statistics). Table: 8.49, 8.55.

http://www.cbs.gov.il/reader/shnaton/templ_shnaton.html?num_tab=st08_49\&CYear=2009

http://www.cbs.gov.il/reader/shnaton/templ_shnaton.html?num tab=st08_55\&CYear=2015 


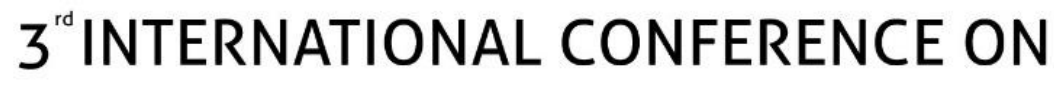 FUTURE OF TEACHING \& EDUCATION}

\section{Stockholm, Sweden}

\section{9-11 October 2020}

The figure indicates that from the early 1990s to the late 2000s a conspicuous increase was evident in the number of Israeli students in technological and scientific academic programs. Upon their graduation, these students were employed in the local labor market with its desperate need for workers with a technological and scientific education, leading to an increase in the number of employees in local advanced industries, as evident from the following figure.

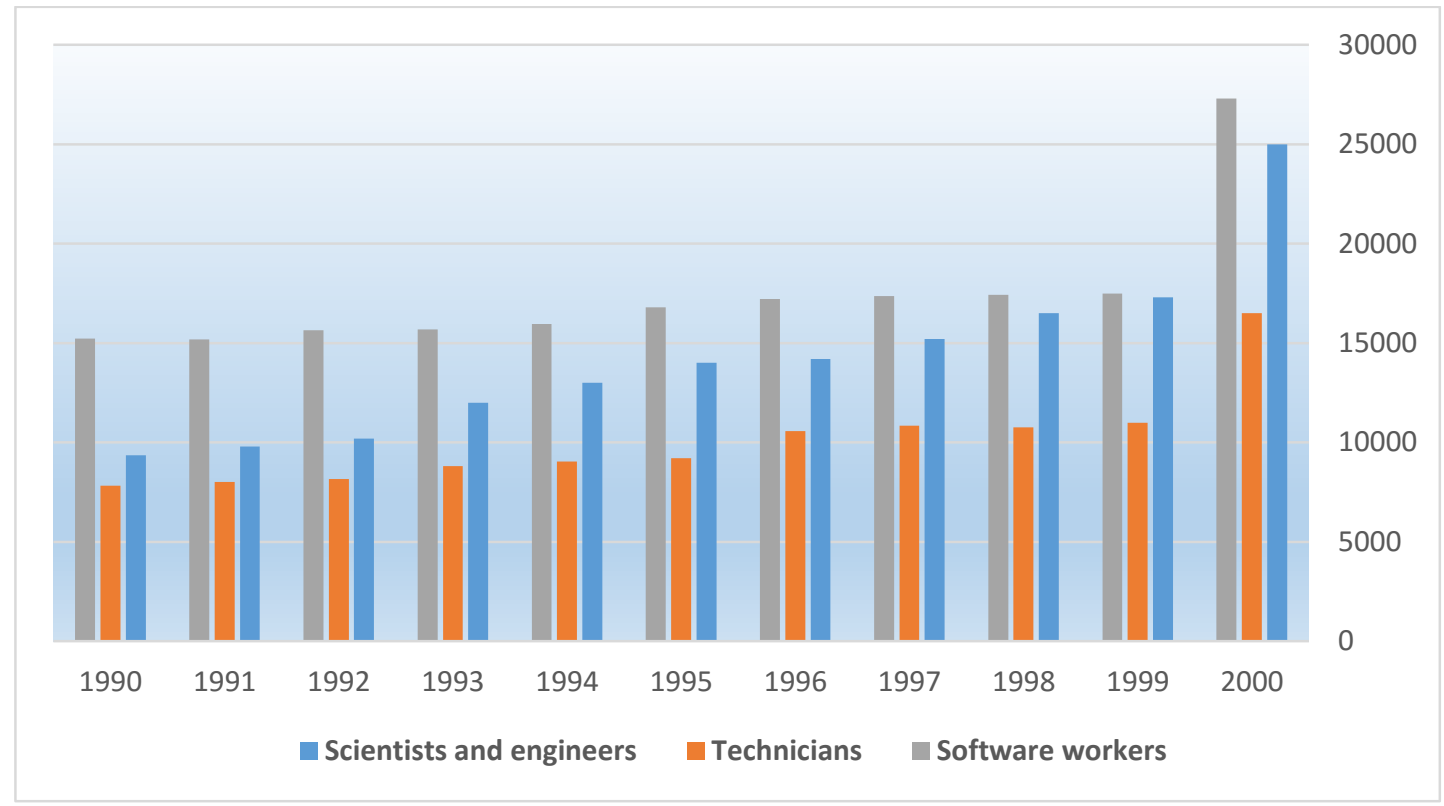

Figure 2: Direct employed persons in advanced industries in Israel 1990-2000.

Source: Israeli CBS (Central Bureau of Statistics). Table 2.56: Employed persons, by occupation.

The rapid technological developments in the 1990s, in the world in general and in Israel in particular, may have led to the growing demand for employees in Israel's advanced industries, ultimately reaching a situation of surplus labor (jobs) by companies and employers over and above the supply of suitable employees for work in this field at that time (alternately, the demand for workers in the advanced industries was higher than the supply of potential workers). As a result, the initially higher employment terms in these industries continued to improve until a conspicuous disparity was evident when compared to employment terms in other industries. Young Israelis were aware of this and rapidly filled the technological and scientific study departments at the various academic institutions with the aim of acquiring academic training that would prepare them for employment in the advanced industries. Therefore, it seems that the increasing demand for computer, exact sciences, and engineering studies in the 1990s was a response to the growing supply of jobs in this field. The rising demand for scientific and technological studies led, in a relatively short time, to an increase in the supply of personnel with appropriate schooling for the advanced industries and, thus, to a rise in the number of employees in these industries.

Therefore, examination of the association between the labor market and higher education seems to show, in this case, that trends concerning the supply of jobs in the local labor market are an initial factor to which the system of higher education responded with changes in the 


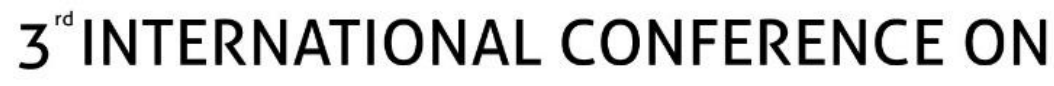 FUTURE OF TEACHING \& EDUCATION}

\section{Stockholm, Sweden}

\section{9-11 October 2020}

demand for various study programs. Further on, the products of the system of higher education (i.e., the graduates) shaped the labor market and provided it with educated employees that fit its needs.

Nevertheless, the question is whether the direction of this association is deterministic (determined in advance) and whether the labor supply is always the initial factor that stimulates changes in the demand for higher education, or perhaps changes in the demand for higher education (that do not originate from the supply of labor) lead retrospectively to changes in the structure of employment in the local economy and in the supply of labor in the various fields of employment. In order to explore this question the field of law (employment and education) in Israel, from the early $21^{\text {st }}$ century to the middle of the current decade, will now be presented.

\subsubsection{The demand for law studies versus the supply of jobs in the field of law.}

For many years the legal profession has been considered a respectable and lucrative occupation, all over the world as well as in Israel, therefore constituting a goal for many young Israelis seeking to advance themselves and their family from a socioeconomic perspective and to acquire an education in the legal field. Until the early 1990s, Israel had a small number of institutions of higher education ${ }^{11}$ (only some of which offered law studies). Therefore, the high demand for law studies by those seeking to acquire such an education encountered a low supply offered by the teaching institutions. This resulted in particularly high admission thresholds and a limited number of students who managed to study the prestigious profession. Once the higher education reform was implemented in 1993, leading as stated to the opening of dozens of new academic institutions in Israel (colleges), the supply of institutions teaching law began to grow and, accordingly, admission thresholds diminished. Consequently, there was a conspicuous rise in the number of law students in Israel from the mid-1990s to recent years, as shown in the following figure:

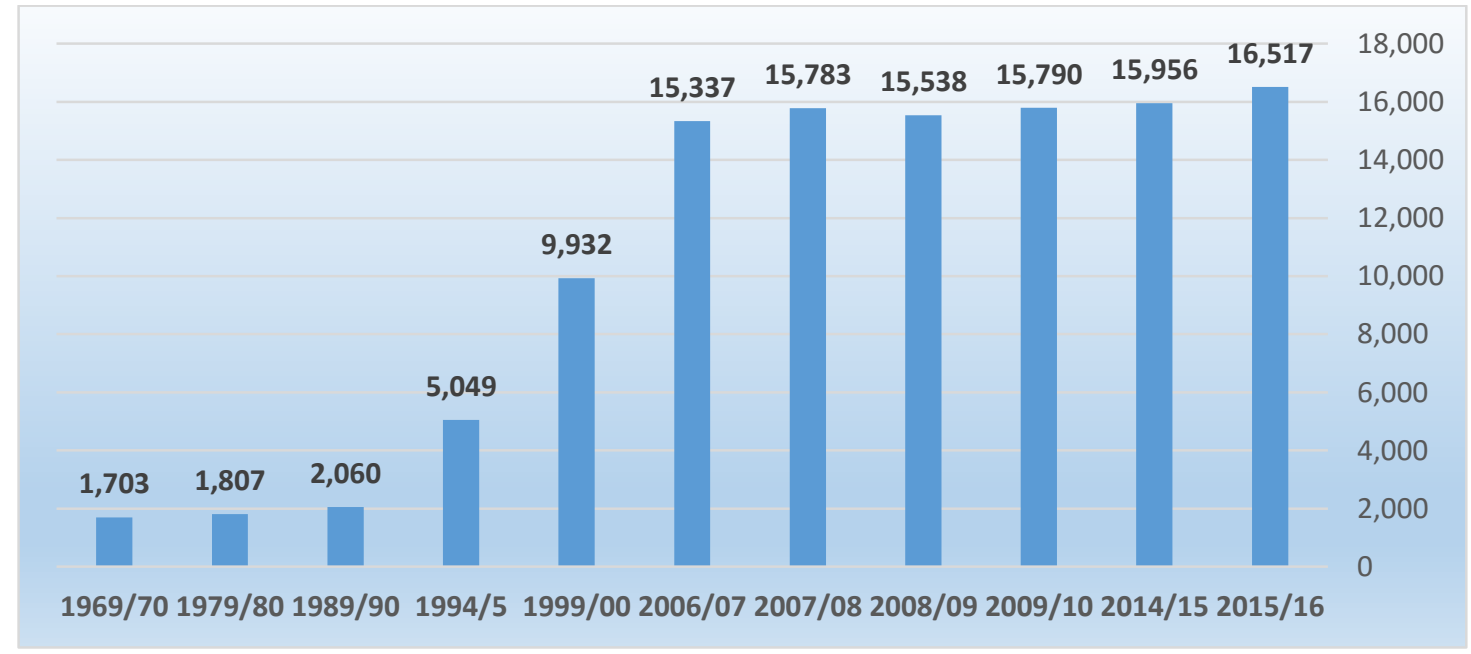

Figure 3 - Baccalaureate degree students in Israel: law.

Source: Israeli CBS (Central Bureau of Statistics). Table: 8.49, 8.55.

http://www.cbs.gov.il/reader/shnaton/templ_shnaton.html?num tab=st08_49\&CYear=2009

http://www.cbs.gov.il/reader/shnaton/templ_shnaton.html?num tab=st08 55\&CYear=2015 


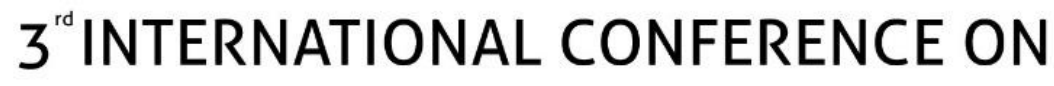 FUTURE OF TEACHING \& EDUCATION}

\section{Stockholm, Sweden}

\section{9-11 October 2020}

The figure shows a conspicuous and consistent growth in the number of law students in Israel since introduction of the reform in higher education. The opening of the colleges facilitated, as stated, an increase in the supply of study slots for this discipline and, concurrently, more flexible terms of admission, until by the end of the first decade of the twentieth century law students at colleges constituted some $80 \%$ of all law students in Israel. A few years later, the large increase in the number of students in this discipline flooded the Israeli job market with graduates seeking employment. Indeed, Figure 4 below shows a rising trend in the number of lawyers and notaries in Israel from the early 1990s to the present. This trend has had conspicuous implications for the legal profession in Israel, including the diminishing prestige of the profession, reduced employment terms in this field, and even a drop in the quality of those engaged in the profession (Cohen \& Davidovitch, 2015).

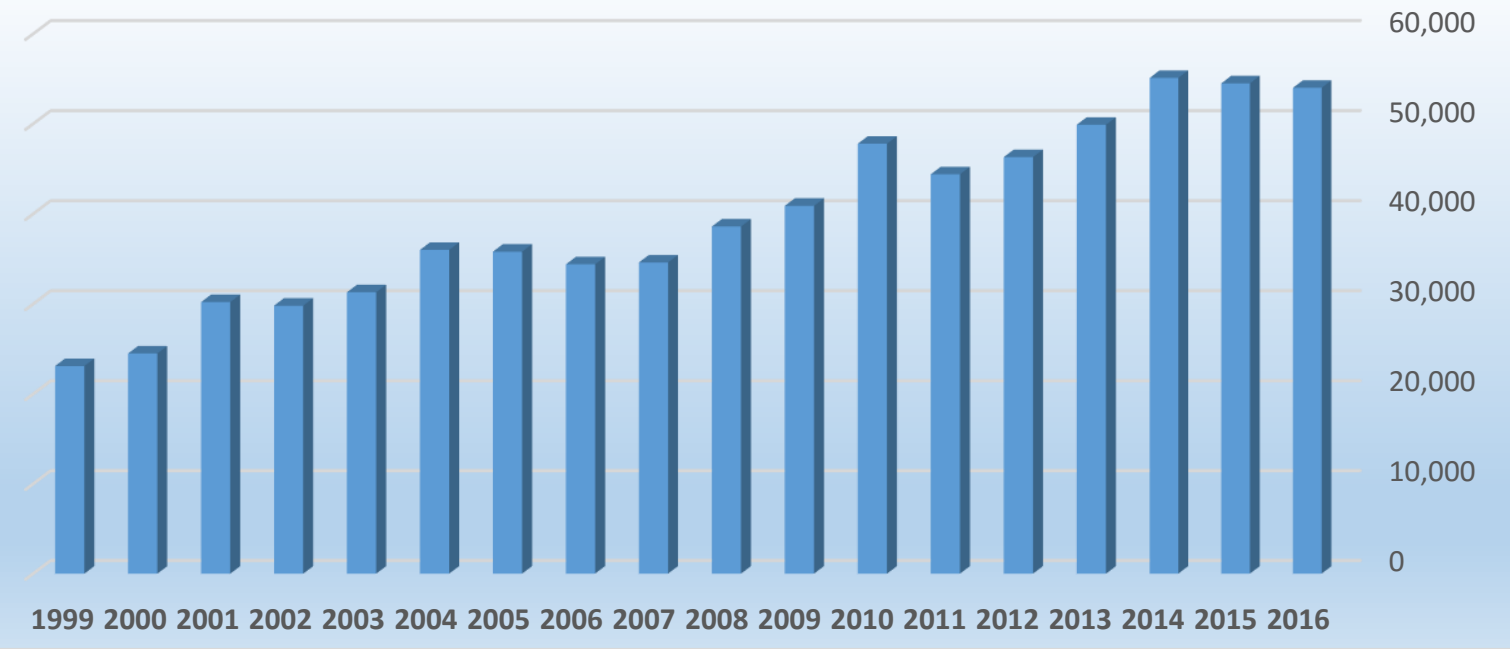

Figure 4 - Number of employed persons in legal and notarial services, Israel, 1999-2016.

Source: Israeli CBS (Central Bureau of Statistics). Table 2.2: Employed persons, by selected industries.

Therefore, it seems that the growing demand for law studies in Israel was not in response to the supply of jobs, rather resulted from social factors related to the desire to obtain a lucrative profession with a high social image. The growing demand for law studies in Israel led, in a matter of years, to an increase in the number of those engaged in law and even to a flooding of the industry and a surplus of workers that created a high demand for jobs. This reality contributed to the diminishing prestige of the law profession in Israel and to a drop in average salaries. Hence, it appears that unlike the advanced technology industry presented above, where the supply of jobs in the labor market encouraged the growing demand for technological-scientific education, here it was the rising demand for law studies that expedited changes in the labor market.

Scrutiny of advanced industry on one hand and law on the other, as presented above, attests to the interactions between the supply of jobs in the market and the demand for higher education. These interactions, if not anticipated, guided, and regulated in advance, might lead to various market failures such as a surplus or shortage of people with specific training in various fields within the local market. In order to prevent these market failures in advance or at least modify 


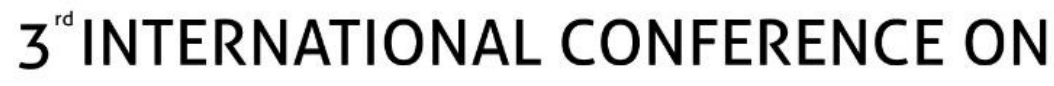 FUTURE OF TEACHING \& EDUCATION}

\section{Stockholm, Sweden}

\section{9-11 October 2020}

them, the government must formulate, plan, and implement public policy regulating the labor market and higher education.

\subsection{Features of Israeli public policy regulating the labor market and the system of higher education.}

Many countries around the world formulate and implement public policy aimed at shaping their system of higher education, due to many varied considerations that include regulation of the labor market and its adaptation to the needs of the local economy (Dill, 1997; NicholsonCrotty \& Meier, 2003; Pasque, 2010; Sin \& Amaral, 2016).

Similarly, the Israeli government (through the Planning and Budgeting Committee, PBC) implements a public policy based on a differential funding model for determining the various subsidy rates awarded to the various institutions (presented below in Table 1). The purpose of this type of model, which reflects the desire of economic leaders to determine the number of employees in the various occupations, is to influence admission policies to academic institutions such that the institutions will be more inclined to accept students to departments for which the government grants higher subsidies and reduce the number of students at departments for which lower subsidies are granted.

\begin{tabular}{lllllllll}
\hline & $\begin{array}{l}\text { Social } \\
\text { sciences }\end{array}$ & $\begin{array}{l}\text { Physical } \\
\text { natural } \\
\text { sciences }\end{array}$ & Engineering & Humanities & Law & Psychology & $\begin{array}{l}\text { Social } \\
\text { work }\end{array}$ & $\begin{array}{l}\text { Business \& } \\
\text { management }\end{array}$ \\
\hline $\mathbf{2 0 1 0 / 1 1}$ & 17.00 & 62.90 & 47.20 & 30.40 & 15.10 & 20.00 & 19.80 & 15.20 \\
$\mathbf{2 0 1 1 / 1 2}$ & 17.30 & 63.90 & 47.90 & 30.80 & 15.40 & 20.30 & 20.10 & 15.40 \\
$\mathbf{2 0 1 2 / 1 3}$ & 18.20 & 67.60 & 50.40 & 32.50 & 16.20 & 21.40 & 21.20 & 16.30 \\
$\mathbf{2 0 1 3 / 1 4}$ & 18.35 & 67.75 & 50.79 & 32.70 & 16.33 & 21.54 & 21.33 & 16.38 \\
$\mathbf{2 0 1 4} / 15$ & 18.57 & 68.56 & 51.40 & 33.09 & 16.53 & 21.80 & 21.59 & 16.58 \\
$\mathbf{2 0 1 5 / 1 6}$ & 18.59 & 68.63 & 51.44 & 33.12 & 16.54 & 21.82 & 21.60 & 16.59 \\
$\mathbf{2 0 1 6 / 1 7}$ & 18.78 & 69.33 & 51.97 & 33.46 & 15.21 & 22.04 & 21.82 & 15.26 \\
$\mathbf{2 0 1 7 / 1 8}$ & 19.05 & 70.33 & 52.72 & 33.94 & 15.43 & 22.36 & 22.14 & 15.48 \\
\hline
\end{tabular}

Table 1: PBC funding rates of universities from 2010/11 - 2017/18 (in NIS thousands) ${ }^{12}$

The data in the table presented above clearly indicate a differential funding policy that reflects the government's preference for promoting specific fields of knowledge in which the country has a national-social stake. This contention is derived from the relatively low funding base provided for students of law, business and management sciences, social sciences, social work, and psychology $(15.43,15.48,19.05,22.14$, and 22.36 thousand NIS per student, respectively), compared to the relatively high funding provided for the humanities, 


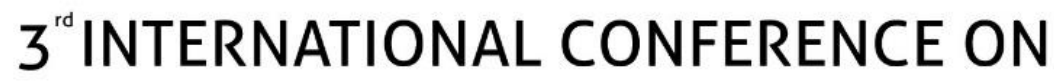 FUTURE OF TEACHING \& EDUCATION}

\section{Stockholm, Sweden}

\section{9-11 October 2020}

engineering, and physical natural sciences $(33.94,52.72$, and 70.33 thousand NIS per student, respectively). ${ }^{13}$

Therefore, it seems that the Israeli government has identified the failures of the free market and its inability to independently regulate the number of students in the various fields of knowledge in a way that meets society's needs. For this reason, the government is attempting, through its policy, to regulate them itself by setting a differential funding model that provides a high financial incentive for academic institutions to accept more students for disciplines needed by the local job market and by Israeli society. On the other hand, it has set a relatively low subsidy rate for fields of knowledge that are less in demand in the local economy as a result of the large supply of employees in this field or the low social demand for these professionals (which has the potential of generating an employment crisis and unemployment).

Nonetheless, it appears that these attempts at regulation are aimed at the teaching institutions and thus impact only supply-related dimensions. Israel's public policy regarding regulation of the job market focuses on attempts to influence the distribution of students in the various study programs by allocating a differential funding base to the various study disciplines guided by ideological considerations (as when promoting the humanities), national considerations (as when promoting engineering and natural studies), and social-employment considerations (as when promoting a drop in the number of law, economics, and social sciences students, in order to prevent an occupational crisis in this field). This policy, however, does not affect the demand for the various study programs, as the demand is created by the candidates who register for studies. Since the public policy does not include incentives and benefits for those registering to study the various programs, this might result in market failures characterized by an excessively low number of academic graduates in disciplines needed by the economy (such as scientific studies) as well as an uncontrolled flow of young people to certain disciplines (such as law) unrelated to the demand in the job market, which will then create a surplus of workers relative to the supply of jobs.

\section{Discussion}

\subsection{Analysis of Israel's public policy regarding higher education: short term versus long term}

Examination of Israel's public policy on planning and regulation of the labor market and of the system of higher education indicates short-term planning. This type of planning takes into account only the occupations active in the economy at a given point in time, is based on data and information with a relatively high level of certainty (age of employees, expected number of retirees, and expected number of academic graduates), and focuses on formulating specific solutions only. Such a policy responds in retrospect to the failures of the free market (in higher education and in the labor market), regulated by forces of supply and demand. This policy is insufficient in order to plan, promote, and shape in advance a better and more suitable reality for the Israeli economy, therefore it may be said that Israel's policy in the field of higher education suits the neoliberal world view that espouses indirect courses of regulation with the aim of creating and encouraging free markets but avoids full involvement in their formation. Utilization of such a policy in critical areas for the country's future is not beneficial 


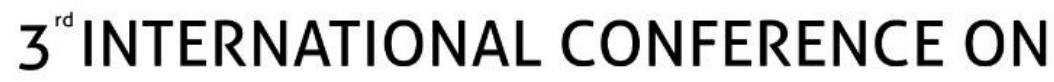 FUTURE OF TEACHING \& EDUCATION}

\section{Stockholm, Sweden}

\section{9-11 October 2020}

from a social-national and economic perspective and might bring about the elimination of Israel's higher education in the near future. At present it is already possible to discern gradually deepening fissures in the fundamental principles of this important system, which strives for excellence, quality, and service and is currently coping with an increasing depreciation of academic degrees (on various levels), departure of young researchers (brain drain), funding difficulties, and even financial collapse of academic institutions, leading to challenging problems in the Israeli labor market as a result of the shortage of certain professionals and a surplus of others.

Contrary to the short-term planning policy, which focuses on specific occupations or disciplines as needed and is based on predictions for the next few years in light of current trends, long-term planning refers to a period of ten years and more. Such planning involves much uncertainty with regard to market trends and attempts to estimate whether current trends will continue or new ones emerge, to prepare for extreme scenarios, potential financial and other crises, empirical predictability, and the availability of suitable funds. Since the planning processes and the necessary resources for coping with long-term forecast conclusions are extensive and multisystemic, sometimes even after thorough predictions it is still essentially difficult to implement the recommendations and conclusions formed. Nonetheless, countries that forecast and plan their future job market in the long term emphasize the significance of these operations, as even though forecasts are known to be deficient and uncertain, the very engagement in this topic and attempts to deal with it are extremely important for formulating future challenges and examining courses of action.

Britain is one example of a country that carries out extensive activities involving long-term prospective planning of its job market and system of higher education. A report of the UK Commission for Employment and Skills wrote on this matter in 2014: "Yet, the way we think about tomorrow influences what we do today. We do not have definitive answers about what is around the corner but we can try to systematically make sense of the direction of travel in the labour market and assess the key uncertainties that we know exist. By analyzing developments in the UK labour market now, we can start to position ourselves for the work needs and opportunities of the future." (UK Commission for Employment and Skills") ${ }^{14}$

Most of the work on forecasts and planning in Britain is performed by the UK Commission for Employment and Skills (UKCES) ${ }^{15}$ in several stages: first, data is collected by means of personnel surveys and skills surveys; second, quantitative forecasts of the workforce size are developed using statistical models; third, qualitative strategic evaluations of the prospective labor market are prepared and recommendations for action issued for the use of citizens, employers, education and training elements, and policy designers. The purpose of this evaluation is to arouse discussion and to portray the efforts and means that can be utilized in order to plan for future challenges and expected opportunities. This information lets individuals in society, decision makers, employers, and elements involved in education and training think about current alternatives and their design in light of future challenges.

Similar to Britain, a quantitative forecast of occupations was carried out in the US as well, by the Bureau of Labor Statistics (BLS). In the US, the forecast referred to the entire population and took into account demographic and economic changes as well as the extent of industrial 


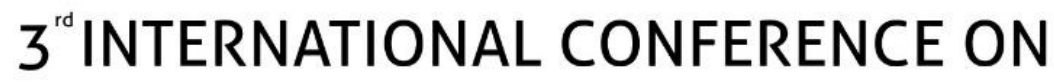 FUTURE OF TEACHING \& EDUCATION}

\section{Stockholm, Sweden}

\section{9-11 October 2020}

manufacturing and manual jobs. The data sources were a personnel survey and a survey of the general population, used to detect historical trends. Evaluations of personnel and of the job market include the rate of occupational turnover, worker retirement, work productivity, and worker wages. The projection takes into consideration several basic premises: overall social and demographic trends will persist, there will be no new significant violent conflicts, there will be no new significant natural disasters, the US economy will be based on full employment, and so on. ${ }^{16}$ Therefore, and from such time as the world can provide examples of public policy predicting and planning the job market and the educational system in the long term, Israel too is advised to forecast the future and perform advance planning of its economy with regard to the occupations and skills that will be required in ten years and more. Moreover, the natural gas discoveries in Israel in recent years are capable of immeasurably changing the Israeli economy and society and strongly impacting Israel's local labor market and system of higher education (Cohen, 2018). ${ }^{17}$

\subsection{Conclusions}

The first purpose of this study was, as stated, to establish the association between the supply of jobs in the labor market and the demand for higher education, while the second purpose was to indicate the direction of the association. In this context, the research conclusions show that there is indeed an association between these two trends and that it is a bidirectional association with interactions between the labor market and the system of higher education. These conclusions are based on two case studies from the Israeli economy: The first case study, which examined the development of scientific and technological studies in Israel in the 1990s, found that the growing demand for computer, exact sciences, and engineering studies in Israel in that period was a response to the increase in the supply of jobs in these fields. Namely, the changes in the supply of jobs led to changes in the demand for higher education. In contrast, the second case study, which focused on law studies in Israel in the last three decades, showed that the growing demand for law studies expedited changes in the supply of jobs in the legal field. Namely, here changes in demand within the system of higher education led to changes in the local labor market.

Another purpose of the study was to examine the public policy implemented in Israel since the beginning of the current decade, a policy capable of influencing either or both of these trends. The research conclusion indicates a public policy that is directed at the short-term and does not derive from long-term planning. This policy, which attempts to regulate the distribution of students in the various disciplines within the system of higher education and to change higher education based on various considerations (economic, social, and ideological) is not sufficiently efficient. Israeli policy attempts to influence the number of students in the various disciplines by implementing a differential funding model aimed at increasing or reducing the incentive of institutions of higher education to admit students to the various disciplines according to the level of government funding provided for them. However, such a policy is completely incapable of influencing demand rather only supply, since as stated it does not include any incentives for those who register to study disciplines to which it gives preference. Moreover, a public policy directed at the short term makes do with examining reality retrospectively and attempting to improve it by regulating students among the various disciplines with the aim of meeting known needs of the labor market (shortages) or correcting

\section{info@icfte.com_www.icfte.com}




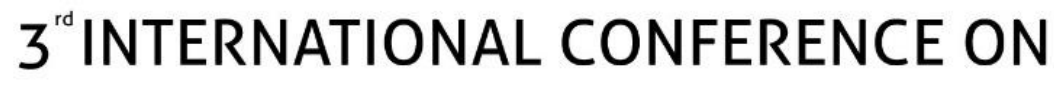 FUTURE OF TEACHING \& EDUCATION}

\section{Stockholm, Sweden}

\section{9-11 October 2020}

its failures (surpluses) in a given period. It does not attempt, however, to examine the future and to try and identify prospective needs and failures that can be predicted by analyzing demographic, technological, cultural, and other trends (as done in other countries around the world, such as Britain and the United States). This limited policy lets free market forces constitute the dominant and even exclusive factor involved in shaping a reality characterized by a shortage or surplus supply of graduates entering the labor market. These shortage and surplus are promptly translated by the teaching institutions into diminishing admission thresholds to less attractive disciplines and unrealistic raising of admission terms to highdemand disciplines. Such an unregulated free market has implications for employment, unemployment, and salary indices in the domestic economy as well.

Therefore, the final research conclusion is that decision makers in Israel should try to examine and analyze global and local future trends and their anticipated impact on the local job market and on the system of higher education and formulate the design of the system of higher education accordingly in advance.

\section{References}

Albert, C. (2000). Higher education demand in Spain: The influence of labour market signals and family background. Higher Education, 40(2), 147-162.

https://link.springer.com/article/10.1023/A:1004070925581

Assaad, R., Krafft, C., \& Salehi-Isfahani, D. (2018). Does the type of higher education affect labor market outcomes? Evidence from Egypt and Jordan. Higher Education, 75(6), 945995. https://link.springer.com/article/10.1007/s10734-017-0179-0

Braw, Y., Cohen, E., Brender-Ilan, Y., \& Sohlberg, I. (2018). A call for establishing a public policy for mitigating the effects of dementia on modern workplaces. Economics \& Sociology, 11(1), 172-187. https://www.economics-sociology.eu/?562, en_a-call-forestablishing-a-public-policy-for- $\quad$ mitigating-the-effects-of-dementia-on-modernworkplaces

Brennan, J., Murray, K., McGeevor, P. A., \& Lyon, E. S. (1993). Students, courses, and jobs: the relationship between higher education and the labour market (No. 21). Jessica Kingsley Publishers. http://eprints.lse.ac.uk/55949/

Cohen, E., \& Davidovitch, N. (2015). Higher education between government policy and free market forces: The case of Israel. Economics \& Sociology, 8(1), 258.

https://www.economics-sociology.eu/files/ES_Vol8_1_Cohen.pdf

Cohen, E. (2015). Development of information technology industries in Israel and Ireland, 2000- 2010. Israel Affairs, 21(4), 516-540.

https://www.tandfonline.com/doi/full/10.1080/13537121.2015.1076183 


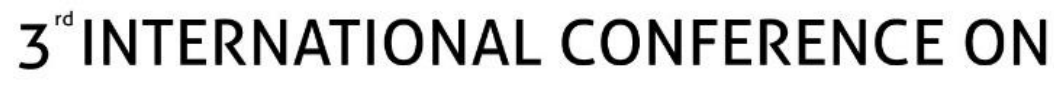 FUTURE OF TEACHING \& EDUCATION}

Cohen, E. (2018). Development of Israel's natural gas resources: Political, security, and economic dimensions. Resources Policy.

https://www.sciencedirect.com/science/article/pii/S0301420717303100

Davidovitch, N., Byalsky, M., Soen, D., \& Sinuani-Stern, Z. (2013). The cost of more accessible higher education: What is the monetary value of the various academic degrees?. Contemporary Issues in Education Research (Online), 6(1), 37.

https://eric.ed.gov/?id=EJ1073228

Dill, D. D. (1997). Higher education markets and public policy. Higher Education Policy, 10(3-4), 167-185.

https://www.sciencedirect.com/science/article/pii/S0952873397000111

Dobbs, R., Madgavkar, A., Barton, D., Labaye, E., Manyika, J., Roxburgh, C., \& Madhav, S. (2012). The world at work: Jobs, pay, and skills for 3.5 billion people (Vol. 28). Greater Los Angeles: McKinsey Global Institute. https://www.mckinsey.com/featured-

insights/employment- $\quad$ and-growth/the-world-at-work

Elias, P., \& Purcell, K. (2004). Is mass higher education working? Evidence from the labour market experiences of recent graduates. National Institute Economic Review, 190(1), 60-74. http://wrap.warwick.ac.uk/68800/

Etshim, R. (2017). Collaboration between Higher Education and Labor Market in Kinshasa, DR Congo. Journal of International Education and Leadership, 7(1), n1.

https://eric.ed.gov/?id=EJ1151006

Frey, C. B., Osborne, M., Holmes, C., Rahbari, E., Garlick, R., Friedlander, G. \& Wilkie, M. (2016). Technology at work v2. 0: The future is not what it used to be. CityGroup and University of Oxford.

https://www.oxfordmartin.ox.ac.uk/downloads/reports/Citi_GPS_Technology_Work_2.pdf

Frey, C. B., \& Osborne, M. A. (2017). The future of employment: How susceptible are jobs to computerisation?. Technological Forecasting and Social Change, 114, 254-280.

https://www.oxfordmartin.ox.ac.uk/downloads/academic/The_Future_of_Employment.pdf

Hamilton, B. H. (2000). Does entrepreneurship pay? An empirical analysis of the returns to self- employment. Journal of Political Economy, 108(3), 604-631.

https://www.jstor.org/stable/10.1086/262131?seq=1\#metadata_info_tab_contents

Nicholson-Crotty, J., \& Meier, K. J. (2003). Politics, structure, and public policy: The case of higher education. Educational Policy, 17(1), 80-97.

https://journals.sagepub.com/doi/10.1177/0895904802239287

Parry, E., \& McCarthy, J. (Eds.) (2017). The Palgrave Handbook of Age Diversity and Work. UK: Palgrave Macmillan. https://link.springer.com/book/10.1057/978-1-137-46781-2

Pasque, P. (2010). American higher education, leadership, and policy: Critical issues and the public good. Springer. https://www.palgrave.com/gb/book/9780230615090 


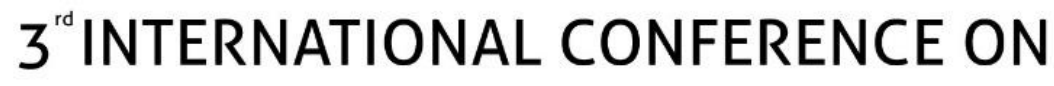 FUTURE OF TEACHING \& EDUCATION
}

\section{Stockholm, Sweden}

\section{9-11 October 2020}

\author{
Sin, C., Veiga, A., \& Amaral, (2016). European policy implementation and higher \\ education. UK: Palgrave Macmillan, 41-62. \\ https://www.palgrave.com/de/book/9781137504616
}

Staudinger, U. M., Finkelstein, R., Calvo, E., \& Sivaramakrishnan, K. (2016). A global view on the effects of work on health in later life. The Gerontologist, 56(Suppl_2), S281-S292. https://academic.oup.com/gerontologist/article/56/Suppl_2/S281/2605634

Van Dalen, H. P., Henkens, K., \& Schippers, J. (2010). Productivity of older workers: Perceptions of employers and employees. Population and Development Review, 36(2), 309330.

https://www.jstor.org/stable/25699062?seq=1\#metadata_info_tab_contents

World Economic Forum (2016). The future of jobs: Employment, skills and workforce. strategy for the fourth industrial revolution. Geneva, Switzerland: World Economic Forum. http://reports.weforum.org/future-of-jobs$\underline{2016 / \text { ?doing_wp_cron }=1543926379.4887878894805908203125}$

\section{Notes:}

1 Employment Projection, 2014-2024, Bureau of Labor Statistics, USA.

2 Most of the jobs that will disappear (about two thirds) are expected to be in the field of office work and administration.

3 For example: the aging population, the rise in the desire to balance work with personal and family life, changes in the work environment as a result of media and information technologies, changes in the nature of the business environment, and more.

4 A shortage estimated at 38 to 40 million workers.

${ }^{5}$ A surplus estimated at 90 to 95 million workers.

${ }^{6}$ For example, jobs in technological firms, management jobs, entrepreneurial work, etc.

7 For example, manual labor, manufacturing jobs, etc.

${ }^{8}$ Until 1993 the law forbade the establishment of non-research educational institutions in Israel, however in that year Minister of Education Amnon Rubinstein decided on a reform in higher education and changed the law. From 1993 to the present dozens of colleges have been established, of which the large majority offer academic study tracks for Bachelor's and Master's degrees in the same subjects taught at the various universities.

9 A study conducted jointly with Oxford University.

${ }^{10}$ Such as computers, natural sciences, and engineering.

11 Six universities and one research institute.

${ }^{12}$ Source: PBC budget books for 2009/10-2017/18, Appendix 5. 


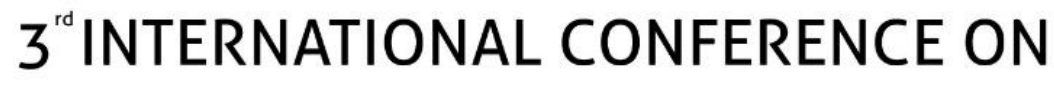 FUTURE OF TEACHING \& EDUCATION}

\footnotetext{
${ }^{13}$ Based on data for 2018.

${ }^{14}$ The Future of Work. Job and Skills in 2030. Evidence report 84, published: 28 February 2014, p. 6.

https://assets.publishing.service.gov.uk/government/uploads/system/uploads/attachment data/file/303334/e r84-the-future-of-work-evidence-report.pdf

${ }^{15}$ UKCES is both a non-departmental public body (NDPB) and a company limited by guarantee (UKCES, Our Governance, date retrieved: 24 January 2016.

${ }^{16}$ BLS, Chapter 13 - Employment Projection, p.1. https://www.bls.gov/opub/hom/pdf/homch13.pdf

17 The anticipated transition to energy based on natural gas will render occupations related to the production and use of other energy sources (such as coal, petrol, and fuel oil) redundant and will also generate a need for workers proficient in fields related to the production and maintenance of systems based on natural gas.
} 